\title{
Hverdagens religiøsitet i og udenfor skolen: Om kirker, nisser og bedetæpper
}

\author{
Iram Khawaja
}

\begin{abstract}
How is religion and religiosity - especially Muslimness - perceived and constructed in school children's everyday life? This is the main question of the article which is explored through an analysis of a photo-project and a mind map session with two fifth grade classes in a school in Copenhagen. The children were given the task of taking pictures of places, people, situations or objects from their everyday lives which they believed were associated with religion or religiosity. The analysis of the images and the mind map produced in the class shows some interesting patterns in regard to the dominant regimes of representations. The visual and material expressions of religiosity are centered on specific religions, namely Christianity and Islam and locations, such as private/public and school/home. These patterns are connected to societal and national discourses on religiosity and secularity, and processes of minoritisation and majoritisation of religious practice. The article also includes reflections on the methodology of using pictures as a visual medium in the exploration of the religiosity of everyday life in and outside the school.
\end{abstract}

\section{Introduktion}

Den danske folkeskole er som samfundsmæssig institution forbundet med nogle særlige praksisser og forventninger om, at man som barn gennem 10 års skolegang kan komme ud på den anden side som en passende og dannet samfundsborger (Korsgaard 2009, Anderson 2011, Gilliam \& Gulløv 2012). I forhold til elever med muslimsk og anden etnisk minoritetsbaggrund ses der et ekstra lag af forventninger tilknyttet, som går på integration og tilpasning i det danske samfund (Khawaja 2001, Kofoed 2004, Gitz-Johansen 2006, Jensen \& Kühle 2013). Det er således ikke kun et dannelsesprojekt men også et integrationsprojekt som skolen i mange tilfælde påtager sig, hvilket kan siges at være forbundet med bredere samfundsmæssige diskurser om nationalitet, sekularitet og religiøsitet (Billig 1995, El Haj 2010). Det rejser flere spørgsmål, som er skolen et sekulært rum? Er der plads til religiøsitet, og hvis der er plads, i hvilke former og på hvilke måder kan religiøsiteten komme til udtryk?

Det er centrale spørgsmål, der er vigtige at stille for at kunne forstå skolens betydning for muslimske skoleelevers hverdagsliv og mulighed for religiøs praksis. Folkeskolen og forskellige andre hverdagskontekster i barnets liv tilbyder hver deres diskursive logikker og sociale strukturer for, hvordan det er muligt at positionere sig som et legitimt og accepteret subjekt. Derfor er det særligt interessant at se nærmere på, hvordan skolen skaber rum for religiøsitet i det enkelte barns hverdag. Jeg vil tage udgangspunkt $\mathrm{i}$ denne interesse $\mathrm{og}$ fokusere på, hvordan religiøsitet italesættes blandt elever i to femte klasser i en folkeskole i København samt fotomateriale produceret af disse elever. Mit fokus er i første omgang på religiøsitet generelt, men det er med særligt henblik på undersøgelsen af, hvordan muslimskhed konstrueres og bliver til i 
folkeskolen. Jeg vil nu komme nærmere ind på artiklens teoretiske ramme og analytiske fokus, hvorefter jeg vil beskrive det forskningsprojekt, som ligger til grund for artiklen.

\section{Hverdagens religiøsitet}

Min tilgang til at forstå skolebørns religiøsitet $\mathrm{i}$ og udenfor skolen er inspireret af en særlig tradition i religionssociologisk forskning, hvor der rettes fokus på hverdagens religiøsitet (Ammerman 2007, McGuire, 2008). Det handler om at undersøge religion og religiøsitet $\mathrm{i}$ og $\mathrm{i}$ sammenhæng med menneskers levede hverdagsliv. Religion og religiøsitet kan ikke ses og undersøges som fastlagte og absolutte størrelser, som fremstår ensartet til alle tider og i alle steder. Man må snarere se på, hvordan religiøsitet er vævet ind i det komplekse stof, som hverdagen er sat sammen af. Meredith McGuire (2008) skriver om den levede hverdagslige religiøsitet og fremhæver:

At the level of the individual, religion appears to be a multifaceted, often messy and even contradictory alamgam of beliefs and practices..(...) Individuals' lived religion is experienced and expressed in everyday practices - concrete ways of engaging their bodies and emotions in being religious... To understand modern religious lives, we need to try to grasp the complexity, diversity, and fluidity of real individuals "religion-aspracticed"(..)(McGuire 2008:208-211).

Der er tale om et perspektiv, der fremhæver og tager som sit udgangspunkt, den daglige praksis, hvilket er et veludviklet forskningsfelt indenfor den bredere sociologiske retning (de Certeau 1984, Sheringham 2000). Spørgsmålet er, hvordan religiøsitet formes og kommer i spil i hverdagen, og på hvilke måder fremtræder religion og religiøsitet som mere eller mindre betydningsfuldt? Hvornår antager noget form som religiøsitet og gives mening i ens liv? Der er således bredt set fokus på i hvilke kontekster og på hvilke måder "religion works" (Ammerman 2007, se også Woodhead 2013)?

Denne hverdagssociologiske indfaldsvinkel til religion og religiøsitet kan sammenholdes med mange fremtrædende socialpsykologiske perspektiver, som retter fokus på hverdagslivet og -konteksten som en af de centrale arenaer for afdækningen og udforskningen af menneskers liv, handlinger og selvforståelser (Staunæs 2004, Mørck 2006, Kousholt 2011). Det er i rutinerne, det mondæne og trivielle, at man kan søge efter de betydninger, mål og lokale sandheder, som mennesker lever deres liv efter. I forhold til udforskningen af børns liv ses det bl.a. repræsenteret $\mathrm{i}$ et fokus på at inddrage og forstå børns hverdagsliv ud fra deres egne perspektiver, og der er efterhånden en rig tradition for at inddrage det, man kalder for et børneperspektiv. Det handler om at forsøge at se verden fra barnets perspektiv baseret på en forståelse af, at barnet er en aktiv deltager i sit liv (Andenæs 1991, Kofoed 2004, Kousholt 2005, Gulløv \& Højlund 2010, Rasmussen 2013). Der er udført en del undersøgelser af børns hverdagsliv med udgangspunkt i barnets perspektiv (Staunæs 2004, Kousholt 2005), men der findes ikke megen forskning om børns blikke på religiøsitet og oplevelse heraf. Religiøsitet 
er således generelt set underbelyst i den eksisterende barndomsforskning, hvilket er problematisk, da det i stigende grad er en kategori, der fremhæves og tages $\mathrm{i}$ anvendelse $\mathrm{i}$ forhold til særligt gruppen af etniske minoriteter i samfundet (Abbas 2007, Khawaja 2010, Olwig \& Paerregaard 2011).

De få eksempler på studier af børn og religiøsitet, der kan nævnes i en international sammenhæng, hvor man har set på religiøsitet er bl.a. David Hellers (1986) og Robert Coles (1990) forskningsarbejde. Heller og Coles inddrager børn som aktive deltagere i forskningsprocessen og forsøger at indfange deres forståelser, forestillinger og fortællinger om tro, religion og Gud. Der synes at være et fokus på at komme om bag tegningerne og ind i "the inner lives of children", som bogserien, som Coles bog, "The Spiritual Life of Children" er en del af, indikerer. Min ambition i mit foto-projekt med de to femte klasser er til dels ens med Heller og Coles, idet jeg også ønsker at inddrage børnenes perspektiver og forestillinger via deres fotos, men målet er på den anden side anderledes, da jeg gennem børnenes fotos ikke har en forhåbning om eller en teoretisk motiveret interesse for at kunne sige noget om børns indre liv og spiritualitet. Jeg søger at udforske hvor, hvordan og hvilke religiøse symboler, handlinger og situationer, der synliggøres i elevernes diskussion med hinanden i klassen og i de fotos, de vælger at tage fra deres forskellige hverdagskontekster. Barndomsperspektivet kombineret med det hverdagssociologiske blik på religiøsitet, åbner således op for muligheden for at kunne se på elevernes fotos som udtryk for deres blikke på, hvor og hvornår "religion works" i deres hverdag. Dog vil mit fokus være centreret om de materielle udtryk for religion og religiøsitet, da det er det, som især indfanges i foto-materialet.

I forhold til hvordan religiøsitet defineres, så konceptualiseres det som en socio-kulturel kategori, der bliver til, formes og defineres via det enkelte subjekts hverdagslige handlinger. Denne måde at forstå religiøsitet er på linje med teoretiske begrebsliggørelser af andre sociokulturelle kategorier som køn og alder, hvor man indenfor bl.a. feministisk forskning, postkoloniale studier og bredt set i socialvidenskaben har set et fokus på kategorier som køn, alder, etnicitet og race, som noget man "gør" (fx Butler 1999, Davies 2000, Brah 2007). Køn ses eksempelvis som et produkt af de materielle og diskursive betingelser, der gør sig gældende $\mathrm{i}$ en given tid, kontekst og sammenhæng, og derfor er køn som socio-kulturel kategori ikke en fastlåst størrelse. Det interagerer og spiller sammen med andre kategorier og gives nye betydninger i enhver social sammenhæng (Søndergaard 1996, Butler 1999, Lather 2007). Jeg argumenterer i linje hermed for samme forståelse af religiøsitet og herunder muslimskhed som en sociokulturel kategori, der er knyttet an til den enkeltes positioneringsmuligheder, handlinger og hverdagsliv. Denne måde at anskue religiøsitet på betyder, at jeg i analysen af elevernes fotos også ser nærmere på, hvad eleverne gør med religion og religiøsitet i deres positioneringer i og udenfor skolen. Jeg vil nu bevæge mig videre til at sige noget om det projekt, som tilvejebringelsen af fotomaterialet har været en del af. 


\section{Projektet: mindmap og fotos}

Projektet, som denne artikel tager udgangspunkt i, er del af et bredere tværfagligt projekt om islam, muslimske familier og den danske folkeskole. ${ }^{1}$ I mit delprojekt har jeg rettet fokus på muslimske skolebørns og deres forældres fortællinger om religiøsitet i hverdagen ${ }^{2}$ og har haft ambitionen om at følge religiøsitet og muslimskheden som en kategori, der antager forskellige former, gives navn og forskelligt indhold $\mathrm{i}$ de kontekster og relationer, barnet indgår i. Jeg ønskede dog ikke kun at inddrage italesættelser og således fokusere på den sproglige dimension af konstruktionen af religiøsitet. Ambitionen var at supplere og eksperimentere med at inddrage visuelt materiale i form af fotos. Fotos som er taget af børn fra deres perspektiv på, hvor og hvordan religiøsitet kommer til syne i deres hverdag. Denne artikel tager udgangspunkt i et sådan fotomateriale, som er produceret af to femte klasser på en Københavnsk folkeskole, og den indledende klassediskussion, som fandt sted om religion og religiøsitet. ${ }^{3}$ Jeg kommer således ind på både billedliggørelsen og italesættelsen af religiøsitet, og de sammenhænge der eksisterer imellem den materielle, visuelle og diskursive konstruktion af religiøsitet i og på tværs af børns hverdagsliv.

Den pågældende skole består af ca. 800 elever. Skolen er placeret i et socialt sammensat område, med mange almennyttige boliger og lejlighedsblokke. Eleverne på skolen kommer primært fra nærområdet. De to femte klasser, som producerede fotomaterialet, bestod af 18 elever $\mathrm{i}$ hver klasse. Elevsammensætningen i klasserne var ligeså sammensat som lokalmiljøet. Andelen af elever med etnisk minoritetsbaggrund udgjorde omkring 35\% på skolen, og det kom til udtryk i klasserne, hvor der var en broget blanding af elever med forskellige religiøse og etniske baggrunde. I de to femte klasser var der dog en ligelig fordeling af elever med etnisk minoritetsbaggrund og majoritetsbaggrund, og størstedelen af dem var efterkommere af indvandrere eller flygtninge. Fotoprojektet blev udført i december 2012, som en opfølgning på tidligere besøg på skolen i løbet af året. Min tilstedeværelse var således ikke fremmed for eleverne i klasserne.

Denne del af projektet var designet således, at jeg med læreren Bente, ${ }^{4}$ som underviste eleverne $\mathrm{i}$ dansk og kristendom, var med $\mathrm{i}$ en undervisningstime $\mathrm{i}$ hver klasse henover to uger. Vi indledte med at

${ }^{1}$ Projektet blev afsluttet i 2013. For nærmere information se, http://icsru.au.dk/projekter/group/schoolislam.dk/

${ }^{2}$ Det empiriske grundlag for projektet består af kvalitative narrative interviews af børn med muslimsk baggrund i aldersspændet 9-16 år og deres forældre samt deltagerobservationer og visuelt materiale $\mathrm{i}$ form af fotos. Jeg har i interviewene forsøgt at følge barnets bevægelser fra hjem, skole og henover andre aktiviteter som klub, sport, modermålsundervisning og koranundervisning, og inddraget fortællinger fra forældrene af disse børn. Jeg har også interviewet tosprogede lærere, for at få et varieret og rigt billede af den hverdag, som børnene tager del i. Materialet strækker sig henover 3 forskellige skoler to indenfor København og en udenfor København i en forstad. Feltarbejdet blev udført henover en periode på 1 år.

3 Der er forskel på religion og religiøsitet, men de er samtidigt meget sammenkoblede. Religion kan siges at angive tro og troslære, hvor religiøsitet henviser til praksis og det at leve efter og forme sit liv i forhold til en bestemt troslære.

${ }^{4}$ Bente er 45 år gammel, og har været lærer på skolen siden 2000. Jeg vil gerne udtrykke stor tak til Bente for hendes samarbejdsvilje og åbenhed. 
præsentere eleverne for projektet og dernæst talte vi med dem om, hvad de tænker om religion og religiøsitet. I samarbejde med eleverne producerede vi et mindmap, som blev skrevet op på white board i klassen. Mindmap var baseret på elevernes frie associationer om, hvad de opfattede som og tænkte, når jeg sagde religion eller religiøsitet. Vi skrev elevernes input op, og fik talt om deres tanker. Det var i denne session også muligt at observere de i klassen eksisterende relationer og måder at tale om religion og religiøsitet. Hvor interviewet og diskussionen i klassen rettede fokus på spørgsmålet, "fortæl mig..?" er produktionen af fotos baseret på spørgsmålet om "vis mig...?" Vis mig, hvad du tænker, føler eller oplever, og dette "vis mig" er forbundet med den fordel, at billederne meget tydeligt kan vise hen til et "hvor" og et "hvad" i konstruktionen af religiøsitet.

Hvis man vil forstå børns hverdagsliv og praksis må man tage højde for, at det sociale er forbundet med rum, sted og materialitet (Barad 1998, Gulløv \& Højlund 2010, Nielsen 2013). Elevernes fotos giver metodisk adgang til at undersøge børneperspektivet og betydningen af det rumlige, stedslige og materielle aspekt (se også Winther 2004) af hverdagens religiøsitet. Linda Woodhead (2013) fremhæver nødvendigheden af at arbejde innovativt, når man forsker i menneskers hverdagsliv.

Research into everyday life may therefore be not so much a matter of getting people to articulate what they already know, but of helping bring to birth things which have not yet been put into words - and which in some cases could never be put into words, but might be captured in a picture, a dance or an object... Research on everyday life prompts us to pay more attention to such things... This requires an approach which takes the body, material objects, symbols and spaces much more seriously, and forges new ways of doing so" (Woodhead 2013:14)

Det gør sig ifølge Woodhead særligt gældende, når det handler om religiøs praksis (se også Dessing 2013: 47-48). Man kan i tråd hermed sige, at det forskningsprojekt, jeg udførte i de to femte klasser netop var udviklet til at kunne indfange en flerhed af indtryk. På denne måde opstår der et andet slags materiale, som kombineret med fotos og mindmaps bidrager til det, som man kan kalde et multisensorisk empirisk materiale (Kofoed \& Staunæs 2014, Rasmussen 2013: 21). Eleverne inviteres til at tage billeder med henblik på at få indsigt $\mathrm{i}$, hvordan og hvor de ser religiøsitet i deres hverdagsliv. De inviteres således med ind $\mathrm{i}$ forskningsprocessen (Staunæs 2001, se også Winther 2004, Rasmussen 2013), og de får mulighed for at producere og konstruere religiøsitet gennem deres egne blikke på deres hverdag indenfor og udenfor skolen. ${ }^{5}$ Jeg vil indlede analysen med at komme ind på et af de mindmaps, som blev produceret, for at give et indtryk af eleverne og konteksten, og dernæst bevæge mig videre til deres fotos.

\footnotetext{
${ }^{5}$ Dorthe Staunæs kalder det for dialogisk forskning, som handler om at skabe rum for forskellige stemmer og blikke (Staunæs 2001).
} 


\section{Religion og religiøsitet - mindmap}

Nedenfor ses det kollektive mindmap, vi fik produceret i den ene klasse.

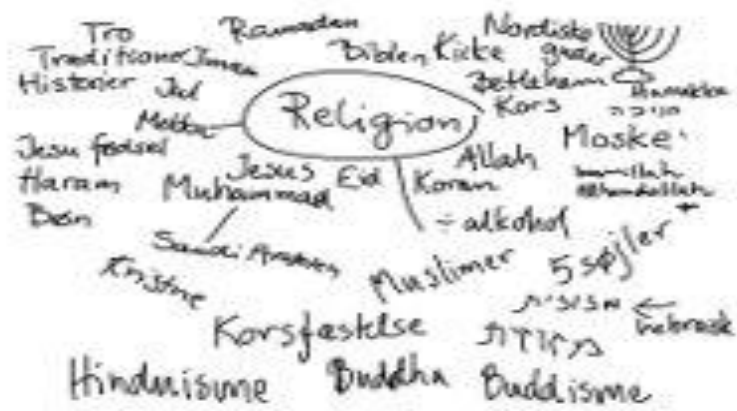

Som man kan se har eleverne i klassen bidraget med mange forskellige associationer til, hvad de tænker om religion eller religiøsitet. Trosretninger som "hinduisme" og "buddhisme" er nævnt i samspil med "nordiske guder", "kristne" og "jul". Der er en overvægt af input, der kredser om islam og kristendom, og hvis jeg rent kvantitativt går til værks og optæller de skrevne input, ser det således ud:

\begin{tabular}{|c|c|c|}
\hline Islam & $\begin{array}{l}\text { Allah, Koran, - alkohol, } 5 \\
\text { søjler, Moske, Mashallah, } \\
\text { Alhumdolilah, Mohammad, } \\
\text { Saudi Arabien, Eid, haram } \\
\text { ramadan }\end{array}$ & 12 input \\
\hline Kristendom & $\begin{array}{l}\text { Biblen, Betlehem, kors, } \\
\text { korsfæstelse, kristne, Jesus, } \\
\text { Jesu fødsel, kirke, jul }\end{array}$ & 9 input \\
\hline Jødedom & $\begin{array}{l}\text { To ord der angiver jødisk } \\
\text { praksis skrevet på hebræisk, } \\
\text { tegning af en ottearmet } \\
\text { lysetage, samt tegning af en } \\
\text { amulet. }\end{array}$ & 4 input \\
\hline Religion generelt & Traditioner, historier, tro, bøn & 4 input \\
\hline Buddhisme & Buddhisme, Buddha & 2 input \\
\hline Nordiske guder & Nordiske guder & 1 input \\
\hline Hinduisme & Hinduisme & 1 input \\
\hline
\end{tabular}

Det er interessant, at elevernes input både henviser til artefakter og objekter (Biblen, kirke, lysestage, Koran), men også i høj grad inddrager højtider og hverdagslige handlinger (jul, eid, mashallah, bøn). Derudover er der også fokus på lokation. Centrale geografiske steder nævnes, som Betlehem og Saudi Arabien. Steder som er langt fra Danmark i historisk 
tid (Jesus og Mohammads tid), men også i forhold til den geografiske og kulturelle distance.

I klassen var der den dag, hvor vi udførte øvelsen med mindmap, tre piger, som sad ved siden af hinanden, og som repræsenterede hver af de tre større monoteistiske religioner, jødedommen, kristendommen og islam. De fremhævede selv dette, og omtalte sig som praktiserende og troende. Den jødiske pige, som boede med sin familie i Israel, var på besøg i klassen, og hun kunne fortælle om særlige religiøse symboler og handlinger, der kendetegnede hendes hverdag i Israel. De andre elever lyttede nysgerrigt til hendes fortællinger fra en hverdag, som var lokaliseret fjernt fra dem, og de sammenlignede med andre religioner og traditioner. Mange af eleverne med muslimsk baggrund fortalte også om deres dagligdag og hverdagslige religiøse handlinger. Amina fortalte f.eks. at man ofte siger albumdolilah eller bismillah inden man skal til at spise, og en anden elev supplerede med, at man også siger mashallah, når man ser noget, der er smukt. Der er tale om forskellige lovprisninger af Allah, som Amina forklarede, er noget, man 'automatisk' gør. Klasserummet fyldtes således med hverdagsfortællinger om religiøsitet, som oftest var situeret udenfor skolen. Snakken handlede dog ikke kun om personlige oplevelser og handlinger. Den synes også i høj grad at være rettet imod, hvordan det 'typisk' er, når man er kristen eller muslim, hvor det er normerne, ritualerne og det "rigtige" der var i fokus i børnenes refleksioner over, hvad det f.eks. vil sige at være muslim.

Det var tydeligt, at det ikke var første gang, eleverne snakkede om religiøsitet og religion. De trak på en del viden fra deres timer i Kristendomskundskab, hvor de tematisk havde gennemgået forskellige religioner. I forhold til at se på skolen og dens rum for religiøsitet kan man sige, at der på forhånd er skabt et særskilt fagligt rum via Kristendomskundskab. ${ }^{6} \quad$ Vores rammesætning af denne undervisningstime falder i tråd med dette formål og den ramme, men man kan sige at elevernes opgave $\mathrm{i}$ denne time bliver mere løst struktureret, da den ikke er bundet op på noget, de skal læse op til eller lave lektier på. Derfor ses både input, der er baseret på, hvad eleverne har læst, og hvad de ved om de forskellige religioner (faglig viden), men der inddrages også hverdagslige fortællinger om deres erfaringer med religiøs praksis (personlig erfaring).

\section{Engangskameraet - analysen af visuelle fortællinger om religion og religiøsitet}

Efter mindmap og klassediskussionen om religion og religiøsitet fortalte jeg eleverne om deres opgave, som var at tage billeder af ting, steder eller situationer fra deres hverdag, som de tænkte udtrykte noget "religiøst". Der var ikke sat begrænsninger på, hvilken religion eller hvor de skulle tage billederne henne, men hver elev skulle tage mindst to-tre billeder. Hver elev fik uddelt et engangskamera, men for mange af eleverne var engangskameraet et ukendt redskab, hvilket siger noget om, at engangskameraer $\mathrm{i}$ forhold til børn og unge i dag på mange måder er et

\footnotetext{
${ }^{6}$ Det hedder 'kristendomskundskab', men undervisningen retter sig i dets formålserklæring bredt imod religion og forskellige religiøse praksisser (uvm.dk).
} 
out-dated redskab. Mange af eleverne måtte have en instruktion i brugen af kameraet. Idéen bag anvendelsen af engangskameraer var, at alle skulle have de samme forudsætninger for at deltage i projektet. Jeg kunne f.eks. ikke forudsætte, at alle havde mobil. Jeg var påpasselig med ikke at synliggøre de sociale skel, der kunne være i klassen, og derudover anvende elevernes personlige ejendele som del af forskningsprojektets tilvejebringelse af empiri. Af forskellige etiske såvel som forskningsbaserede hensyn valgte jeg engangskameraet, men er blevet en erfaring rigere. Ulempen ved elevernes ringe kendskab til brug af engangskamera i samspil med engangskameraets begrænsede teknologi, hvor man ikke kan slette billedet, eller efterfølgende se eller korrigere billedet ved et enkelt swipe, er, at output fra de fremkaldte billeder er af meget varierende kvalitet. Jeg stod tilbage med en del tomme, uklare og grå billeder. Ikke desto mindre opstår der, når de resterende fotos bliver lagt sammen, interessante kollager fra børnenes forskelligartede hverdage indenfor og udenfor skolen.

Stuart Hall (2001) skriver, at visuelle medier som film og billeder producerer særlige repræsentationer af personer, steder, tid og tanker. Der er tale om tegnsættende praksisser (Hall 2003, Staunæs 1998: 156, Rasmussen 2013), og på denne måde kan et billede repræsentere mange forskellige slags betydninger. Analysen af et billede må således tage højde for mange forskellige influerende elementer, så som konteksten, motivet og fotografen. På den ene side kan man sige, at et foto dokumenterer en bestemt virkelighed. Det er en fastfrysning af et bestemt moment, og fungerer således som et artefakt. På den anden side er fotoet via barnets blik og specifikke position og lokation netop et bestemt perspektiv på denne virkelighed. Alle billederne udtrykker en konstruktion af et særligt stykke social virkelighed, som i min analyse og i projektet er sat ind i en ramme af "religion og religiøsitet". Dét, at jeg har sat billederne sammen $i$ en kollage er en yderligere konstruktion, hvor elevernes individuelle bidrag sættes sammen $\mathrm{i}$ en fælles ramme, der skaber et umiddelbart broget indtryk af nisser, koraner, kirker og bedetæpper.

Jeg vil i nærværende analyse både se på kollagen som en helhed og på individuelle billeder, som kollagen er udgjort af, og fokusere på de mønstre, der kan fremanalyseres i foto-materialet - først i forhold til indholdet af motiver, og dernæst i forhold til lokationerne; ude/hjem og privat/offentlig.

\section{Islam og kristendom}

Ved første øjekast på kollagerne fremstår særligt kristendom og islam som dominerende i børnenes valg af motiver, symboler og steder. Det er sammenfaldende med det mønster, der trådte frem i ovenstående mindmap, hvor der var flest input associeret med henholdsvis islam og kristendom. Det overordnede blik på kollagerne viser billeder af islamisk religiøs praksis, som at læse koranen, at bede på bedetæppet, at gå med tørklæde, i kombination med billeder af julepynt, Thors hammer samt den lokale kirke. Hvis vi dykker ned i billedet af Thors hammer, ses en lille hammer, der er skåret ud i sten som et vedhæng i det, som virker som en tynd læderstreng. 

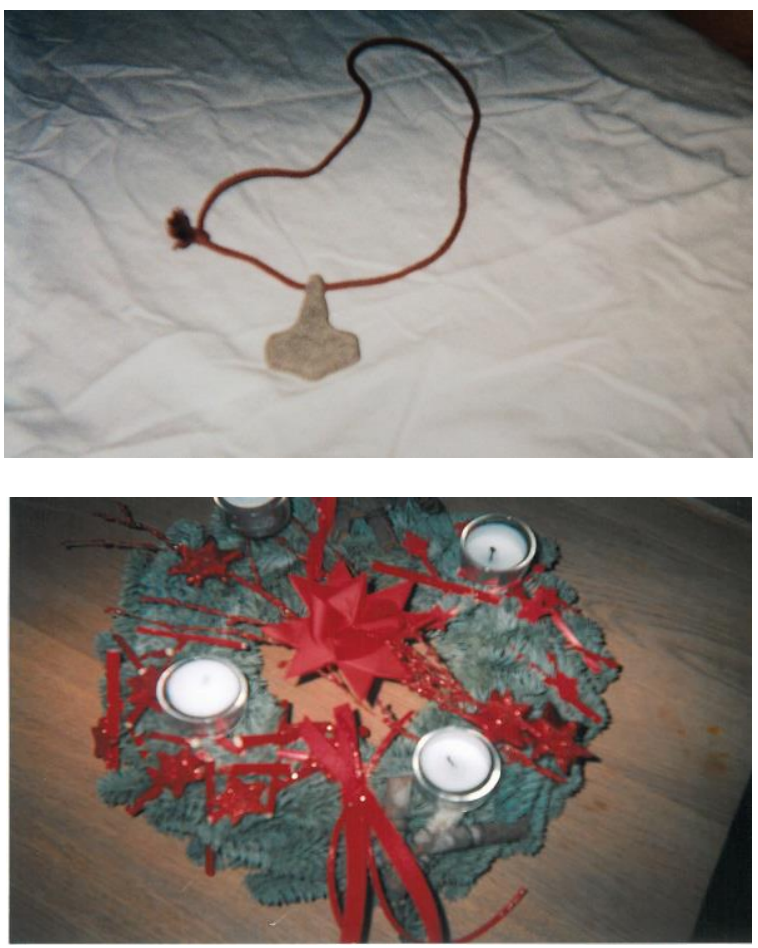

Det er en halskæde, der kan siges at symbolisere nordisk mytologi og vikingetiden. Thors hammer er et symbol for en oldnordisk religiøs praksis, som er en del af den danske nationale kulturarv og historie. Billedet er taget indendørs og baggrunden er et hvidt lagen eller klæde. Man får indtryk af, at det er et billede fra den hjemlige sfære, og at det således højst sandsynligt har været et objekt, som har været tilgængeligt for eleven, og som i det moment billedet er taget, har været tolket og set, som udtryk for noget religiøst. Samme elev har også taget billeder af fire stofnisser, der sidder på en skænk med et maleri i baggrunden, af en adventskrans hvor tre af stearinlysene har været tændt, af en julestrømpe til julemanden og af nogle øreringe, hvor man svagt kan ane nogle kors.

Alle billeder er taget indendørs - måske fra elevens eget hjem. Billederne repræsenterer jul og traditioner, som bl.a. er forbundet med kristen religiøs praksis. Dermed ikke sagt, at eleven kan positioneres som praktiserende kristen og troende. Der er tale om glimt fra hverdagen, hvor man kan se nogle forbindelser til en praksis, som er associeret med religion. Her er det værd at have in mente, at det er de fysiske, materielle og symbolske udtryk for religiøsitet, man særligt får adgang til via billederne, men at de henviser til særlige praksisser og handlinger $\mathrm{i}$ hverdagen, som kan være associeret med religiøsitet. Adventskransen og de tre lys, der har været tændt er et eksempel herpå.

På samme måde ses der øjebliksbilleder af religiøs praksis i hjemmet hos en anden pige i klassen, som indeholder islamisk religiøse symboler. Fotoserien består af billeder af en pige, der går med tørklæde, af et bedetæp som er rullet ud, af en tallerkenformet vægdekoration, med et billede af Mekka. Der er også et foto af syv te-glas i marokkansk stil i 
forskellige farver og en lille tekande i sølv, som er placeret på et hvidt spisebord, ved siden af en lille bog, hvor der står Allah på arabisk.

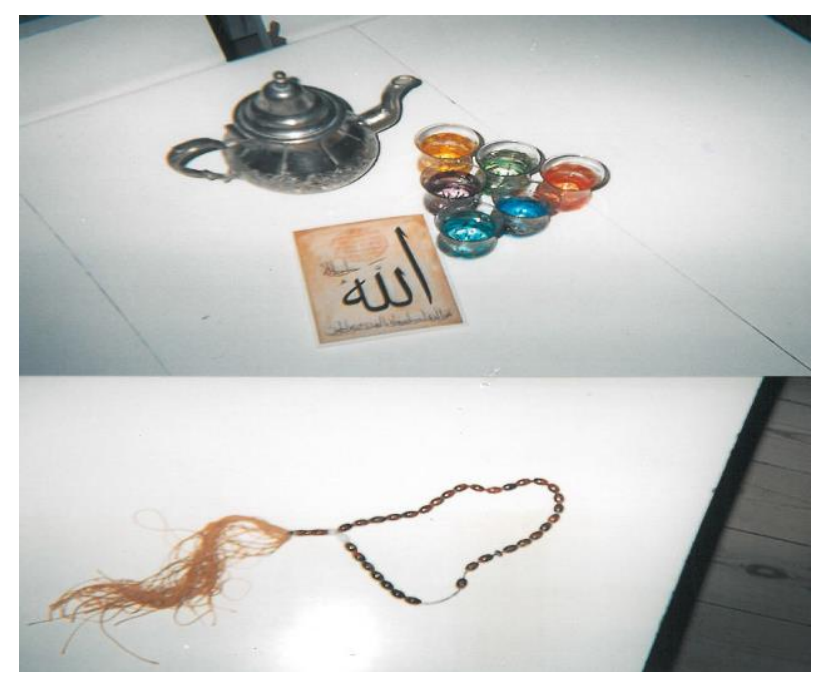

Billedet med te glassene er interessant, da glassene og tekanden udover at indikere en mellemøstlig oprindelse ikke umiddelbart kan siges at signalere religiøs praksis, hvis ikke den lille bog med Allah skrevet på forsiden var placeret ved siden af. På denne måde virker billedet iscenesat. Eleven virker til at have gjort en indsats for at udtrykke, at denne situation har med religion eller religiøs praksis at gøre. Alle disse billeder er også taget indendørs, og giver os således et unikt indblik i de objekter og situationer, som for eleven associeres med religiøsitet. Der er på denne måde tale om særligt situerede blikke på elevernes virkelighed og hverdag - og netop situeringen af blikket er interessant at se nærmere på, for hvem bliver eleverne til, når de gør religiøsitet til objekt for deres blikke og hvilke slags religiøsiteter er mulige at synliggøre?

\section{Elevpositioneringer}

Fotografering er i sig selv en konstruktionsproces, som ikke kun implicerer konstruktionen af det, som man gør til objekt for sin kameralinse, men ligeledes af det subjekt, der står med kameraet. Religiøsitet som er den overordnede ramme for foto-projektet kan både siges at blive gjort til subjekt og objekt i billederne. Børnene tager billeder af religiøsitet, men deres fotos kan repræsentere andet og mere end det. Deres fotos fortæller også noget om de positioner, hvorfra billederne er taget, og dermed af de subjekter, der bliver til gennem kameraets optik. Eleven, der tager billede af adventskransen kan f.eks. siges at blive til som et subjekt, der har julehøjtiden og dens traditioner tæt ind på livet. Når man således får indblik i elevernes privatsfære, ses ikke blot glimt af hjem som en fysisk lokation. Man får ligeledes indblik i de steder, situationer og objekter, som er vigtige for ham eller hende, og som associeres med religion eller religiøsitet. Denne handling kan siges at pege på, hvordan det subjekt, som har taget billedet positionerer sig selv og i det moment billedet er taget, selv er positioneret. 
Positioneringsbegrebet er i denne forbindelse relevant at hæfte sig ved, idet det både dækker over interaktiv positionering og refleksiv positionering (Davies \& Harré 1990). Det vil sige, hvordan man bliver positioneret af den anden, som man enten direkte eller indirekte er i interaktion med, og hvordan man positionerer sig selv. I de billeder som eleverne har taget, bliver de til som subjekter, både gennem mit blik på deres fotos, men samtidigt også gennem de blikke, de skaber billederne igennem. Den refleksive og interaktive positionering kollapser således i og med, at subjekt og objekt sammenvæves i de fotos, som eleverne har taget fra og af deres hverdag. De bliver på denne måde via billeder positionerede og positionerer sig selv som f.eks. "religiøse", "ikkereligiøse", "skoleelever" og "børn" ved i mere eller mindre grad at synliggøre religiøsitet som forbundet med deres egen hverdagspraksis.

I billeder fra skolen fremtræeder de mere tydeligt som skoleelever, imens billederne fra privatsfæren peger hen imod andre mulige positioneringer. Den fotoserie som ovenfor er beskrevet hvor te-glassene og billedet af bedetæppet fremtræder, synes eksempelvis at signalere, at der er tale om en muslimsk elev, som har taget billeder fra sin hverdag. Billederne siger naturligvis ikke noget om i hvor høj grad eleven er praktiserende og religiøs, men de indikerer at der er nogle materielle religiøse symboler og handlinger, der er synlige dele af elevens hverdag særligt hverdagen udenfor skolen. Det peger imod et andet centralt mønster på tværs af elevernes billeder, nemlig hvor og hvordan skolen som kontekst bliver synlig i elevernes fotos af religiøsitet, hvilket fører mig til betydningen af lokation.

\section{Lokation og religiøsitet}

Børnenes blikke på religion og religiøsitet i hverdagen udtrykkes på mange forskellige måder, og man får øje for, at religiøsitet og religion:

..does not exist in a discrete, tidy social box. The religious domain frequently overlaps with other aspects of social life. Events and experiences in the social world take on multiple, yet equally genuine, meanings (Munson 2007: 127).

Kollagerne manifesterer dette, idet det religiøse ikke kun ses repræsenteret på en måde eller i en bestemt social sfære. Nogle steder er skolen repræsenteret meget tydeligt og $\mathrm{i}$ andre billeder er det den hjemlige/private sfære, der dominerer. De forskellige billeder inddrager forskellige sociale domæner og vækker mange forskellige associationer end blot det religiøse. Billederne viser på denne måde, at det religiøse er mange ting, og at det kan situeres i forskellige lokationer. Når jeg grupperer billederne i forhold til lokationer, træder følgende tre hovedlokationer frem:

\section{1. hjemmet/privatsfæren \\ 2. skolen \\ 3. lokalmiljøet omkring skolen}

Hvis vi ser på første gruppering af billeder, så har jeg allerede ovenfor været inde på, at mange af billederne af religiøse symboler, som f.eks. 
kors, Koranen, adventskransen, bedetæppe osv. findes indenfor hjemmesfæren. De er taget indendørs, og man får små glimt af stuer, senge, sofaer og spiseborde. Det er ikke til at vide om alle billeder er taget $\mathrm{i}$ elevernes egne hjem, men synligheden af islamiske religiøse symboler, handlinger og artefakter ses særligt i privatsfærens rammer. Det ses på tværs af billederne fra andre elever i klasserne, som har muslimsk baggrund. Julen fremtræder både i fotos fra privatsfæren, men også fra skolen.

I anden gruppering af billederne fra skolekonteksten ses, at skolens mange forskellige rum inddrages, såsom skolegården og klasseværelset, og at de ofte indeholder billeder af papirklip, nisser og andre symboler forbundet med julehøjtiden.
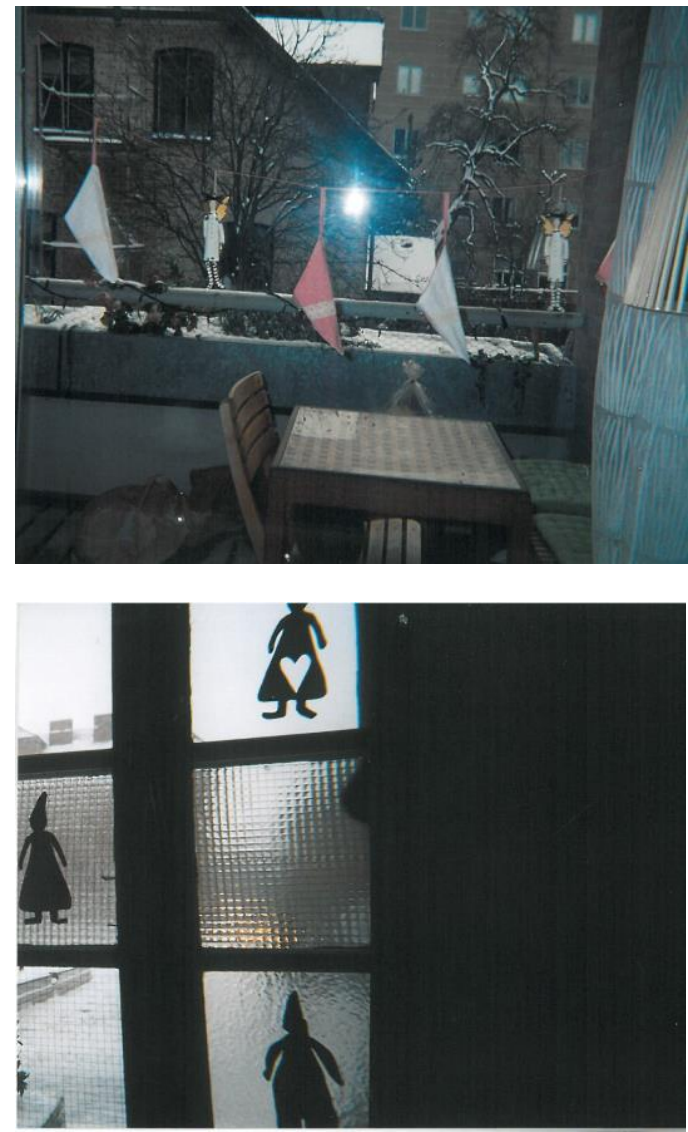

Det er interessant at tænke på, hvordan skolen ville blive repræsenteret $\mathrm{i}$ forhold til religion og religiøsitet, hvis fotoprojektet var blevet udført i en anden periode end december. Julen synes at være det mest dominerende motivvalg inden for skolen. Man ser ikke muslimske symboler repræsenteret inden for skolens rammer på nogen af billederne. Undtagelsen er et billede af en pige med tørklæde på, som sidder $i$ et klasselokale. I nogle fotos er religiøsitet tilsyneladende slet ikke til stede, som f.eks. billedet af en murstensvæg med aftryk af utallige snebolde, 
som er blevet kastet imod den. Væggen hører til skolegårdens rum, men man kan ikke spore nogen form for umiddelbar religiøs association i billedet.

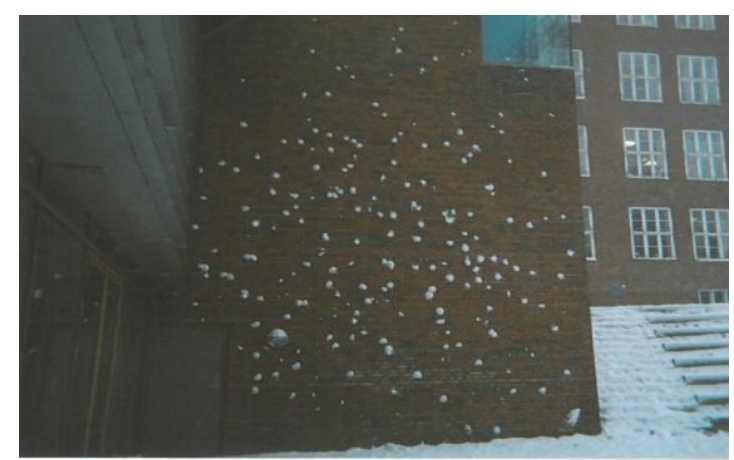

Sneboldenes fastfrosne aftryk udtrykker vinter og kulde og vidner om børns leg i skolegården. Positioneringen som skoleelev og subjektpositionen som deltager i skolegårdens rum bliver antydet via billedet, men det er ikke tydeligt om og hvordan religiøsitet får betydning her.

Lokalmiljøet omkring skolen er i stærkest form repræsenteret ved billeder af den lokale kirke, som er placeret tæt på skolen. Eleverne har taget billede af kirken, kirkens dør samt de religiøse motiver, der er indfældet i sten på kirken.

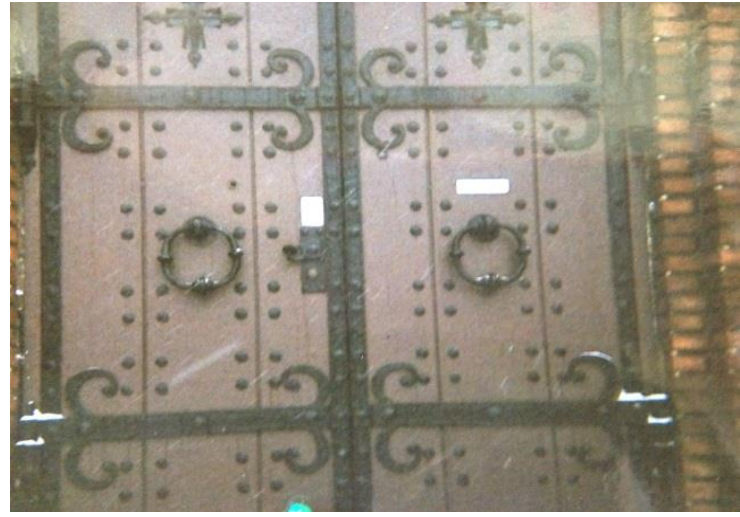

7Jeg har ikke inddraget flere fotos af kirken for ikke at afsløre skolens lokation og navn. 


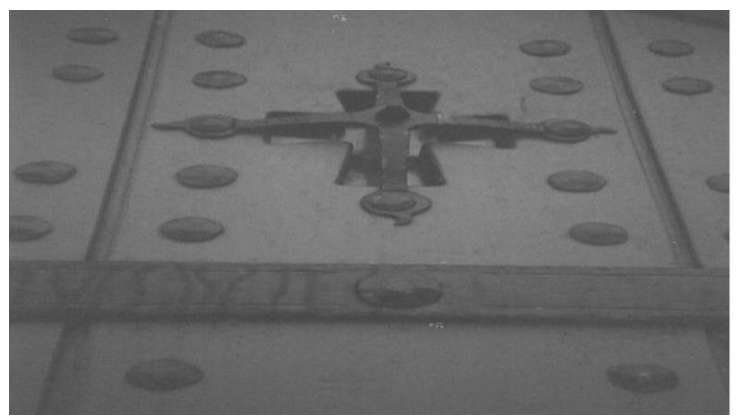

Kirken optræder meget i kollagerne, hvilket indikerer at kirken fylder en del i elevernes hverdagslige landskab. Kirken vækker umiddelbare religiøse associationer, og det er derfor ikke mærkværdigt, at størstedelen af eleverne har valgt at tage et billede af den.

Hvordan er det muligt at forstå betydningen af disse lokationer, og valg af images på tværs af elevernes forskellige hverdagskontekster?

\section{"Regimes of representations"-ude-hjem/offentlig-privat}

Hall fremhæver, at der eksisterer særlige "regimes of representations" (2001: 340) i forhold til, hvordan det er muligt at synliggøre bestemte emner. Der er f.eks. særlige måder at synliggøre og fremstille racialiserede forhold imellem sorte og hvide $\mathrm{i}$ et samfund, som opnår accept og i nogle tilfælde udgør en fælles diskursiv forståelsesramme for, hvordan virkeligheden ser ud og bør ses. På samme måde kan man tale om, at kollagerne peger på, at der eksisterer særlige "regimes of representations" for, hvordan religiøsitet kan repræsenteres og synliggøres. Motiverne i elevernes billeder er ikke kun influeret af den fælles mindmap session i klassen, af elevernes forskelligartede erfaringer med religiøsitet og af den lokale hverdagskontekst, men også af bredere diskursive og magtrelationelt strukturerede hierarkiseringer af det religiøse i forhold til det ikke-religiøse, og af hvor der er plads til religiøs praksis i hverdagen.

Eleverne kan siges at trække på disse regimes of representations, men man kan også anføre at samfundet og herunder skolen som kontekst er struktureret via disse diskursive regimes. Det er f.eks. et faktum at særligt kristendommen og islam er de to religioner, der er mest synlige i det danske samfund. Det kommer både til udtryk i klassediskussionen samt i billederne. Derudover er der specifikke lokationer og sfærer, hvor islam og kristendom kan komme til syne. Man kan i denne forbindelse tale om særlige religiøse "spaces" eller "imaginaries" (Fadil 2009, Jouli 2009).

Et samlet blik på kollagerne viser et mønster, hvor den religiøse praksis $\mathrm{i}$ form af muslimskhed er hensat til den private sfære imens kristenheden (i form af jul og kirke) er synlig både i det offentlige og det private rum. Når skolen kommer i spil er det i forhold til juletradition, og man kan i denne forbindelse diskutere, hvor meget religion, der er ved juleklip og- pynt? I skolen er særligt islam fraværende, men islam bliver omvendt meget tilstedeværende i den private sfære, og man kan i denne forbindelse tale om et særligt skole-hjem mønster $i$ forhold til, hvor muslimskheden bliver synlig, som en del af elevernes hverdagspraksis. 
I kollagerne fremstår muslimskhed som en privatiseret religiøs praksis, hvilket kan læses som udtryk for eksisterende diskurser om adskillelsen imellem det offentlige og det private rum - og diskurserne imellem det sekulære og det religiøse (Asad 1993, Hirschkind 2011, Dessing et al 2013, Khawaja 2014). Talal Asad analyserer på overbevisende vis, hvordan religiøsitet i vestlige samfund ofte hensættes til en privatiseret religiøs praksis (Asad 1993), hvilket er forbundet med konstruktionen af en særlig diskurs om sekularisme. Offentlige institutioner som skolen, defineres som udgangspunkt som sekulære (Jensen \& Kühle 2013). Der er plads til, at eleverne kan lære om religion som fag, men den danske folkeskole er ikke konteksten for udlevelsen af religiøs praksis og tro. Den må situeres andre steder, særligt i den hjemlige sfære.

Adskillelsen imellem det offentlige rum, hvorunder skolen kan siges at være en del af de i samfundet eksisterende institutioner, og det private, er præget af disse eksisterende diskurser og "imaginaries" om religiøs og sekulær praksis (Fadil 2009). I forhold til elevernes fotos, synes det særligt at gøre sig gældende i forhold til, hvor muslimskheden kommer til syne. Denne forståelse af religion som privat kommer også til udtryk i Marianne Holm Pedersens datamateriale over skolelæreres og muslimske forældres forestillinger om religiøs praksis (se artikel dette nummer), samt i Laura Gilliams observationer, hvor det religiøse opfattes som noget der ikke er relevant i skolen (se artikel dette nummer). I mit materiale ses, at denne privatiserede religiøsitet reproduceres og konstrueres fra elevernes perspektiver. Det kommer også til udtryk i de mange interviews, jeg har foretaget med eleverne, hvor f.eks. Mehmet som går i en af de to femte klasser, i forbindelse med beskrivelsen af sin religiøse praksis omkring bønnen, tydeliggør, at det er noget han gør for sig selv i det private (Khawaja 2014).

\section{Minorisering og majorisering af religiøs synlighed}

Kirken fremstår i det offentlige rum, og bryder umiddelbart med, hvordan synliggørelsen af religiøs praksis og religiøsitet er opdelt i det offentlige og det private, men her er det netop værd for det første at være opmærksom på, at kirken $\mathrm{i}$ sig selv kan siges at repræsentere et adskilt religiøst rum. Dernæst at der er bestemte magtrelationelle "regimes", der strukturerer synliggørelsen af "det religiøse", hvor islam og muslimskhed kan siges at repræsentere en minoriseret religiøsitet, imens kristendom og et af dets stærkeste symboler, kirken, repræsenterer en majoriseret religiøsitet (Asad 1993, Korsgaard 2012, Lægaard 2012). På denne måde kan man sige, at kirken er udtryk for den majoriserede, institutionaliserede og "hypervisible religiøsitet" (Dessing et al. 2013), som er en del af den nationale selvforståelse.

Dette majoriserede forhold kommer også for så vidt til udtryk i skolen, ved at det fag hvor eleverne undervises om religion, hedder Kristendomskundskab og at undervisningen i Kristendom prioriteres i forhold til andre religioner, særligt på de små klassetrin (Sedgwick 2014). Adskillelsen imellem ude-hjem/privat-offentlig kan altså også læses ud fra et fokus på det magtrelationelle forhold imellem minorisering/majorisering. Den privatiserede religiøse praksis gør sig gældende for netop den muslimske praksis, fordi der er tale om en 
minoriseret religion, og fordi islam ikke nyder den samme samfundsmæssige accept og genkendelighed som del af skolens og samfundets nationale selvforståelse. Det peger henimod bredere samfundsmæssige magtstrukturer. Det kan i denne forbindelse siges, at billederne giver adgang til de dele af den muslimske praksis, som ikke fremstår som hypervisible, men som er bundet op på de muslimske elevers levede liv. Et liv der på mange måder er gennemsyret af muslimskhed, men som oftest fremstår mindre synligt $\mathrm{i}$ f.eks. skolens rum eller andre offentlige kontekster i barnets hverdagsliv. Nadia Jeldtoft (2013) peger også på hyper-synlighed i sin analyse af unge muslimers hverdagsliv, men hun kontrasterer den med hyper-privatisering (s. 98). Hyper-synligheden ses hos Jeldtoft i måden muslimer og Islam er kommet $\mathrm{i}$ forgrunden som en andetgjort figur i vesten, og hyperprivatiseringen ses $\mathrm{i}$ forhold til de unge muslimers måder at forhandle deres religiøsitet. Religiøs muslimsk praksis hensættes til det private via forskellige emotionelle strategier, hvilket ses som et udtryk for en minoritetsstrategi - dvs. en måde at forhandle synligheden som muslimsk minoritet.

..everyday tactics aimed at making Islam meaningful in hyperprivatised modalities might, on another level, also express minority tactics for making Islam meaningful in relation to majority sensibilities which define legitimate religion. As such, the tactic of hyperprivatisation is simultaneously a means of inhabiting cultural norms, because a result of privatizing religious practices is that subjects achieve 'a room of their own' in which they can be religious in a mode acceptable to the majority. Through privatization, what takes place in these inner spaces becomes invisible to the non-Muslim majority and, as such, accepted and normalized in relation to an expectation that all religion - and especially that of a minority - should be private and unintrusive (Jeldtoft 2013: 98).

Jeldtoft præsenterer her et meget interessant perspektiv, som kan sammenholdes med de mønstre af ude-hjem/offentlig-privat, som kommer til syne i min analyse af elevernes fotos.. Hvor hun analyserer unges meget bevidste og reflekterede strategier for og oplevelser af islamisk praksis, er mit materiale med eleverne $i$ de to femte klasser $i$ højere grad udtryk for den materielle manifestation af religiøsitet - og dermed af de steder, hvor muslimskheden kan blive og gøres synlig. Kollagerne siger således noget om betingelserne for muslimsk praksis som en minoritetsreligion. Det hypervisible kan være forskelligt afhængigt af kontekst. I min analyse ses, at kristenhed og symboler forbundet med den tradition er hyper-synlige både i lokalsamfundet og $\mathrm{i}$ skolen, hvilket sammenholdes med kristendommens majoritetsstatus, imens muslimskheden så at sige bliver hypersynlig i den private sfære. Hypersynligheden af islamiske symboler, artefakter og handlinger er således på interessant vis forbundet med en hyperprivatisering. 


\section{Konklusion: Religiøs praksis og positionering}

Hvad kan ovenstående fremanalyserede mønstre; ude-hjem, kristendomislam samt privat-offentlig sige om børnenes hverdagsliv og religiøse praksis, samt betydningen af skolen?

De analyserede mønstre på tværs af mindmap og elevernes fotomateriale siger for det første noget om, at religiøsitet kan være mange ting. Det kan være nordisk mytologi, kristendom, islam, buddhisme, men det kan heller ikke være hvad som helst. Repræsentationerne af religiøsitet følger nogle gængse diskursive mønstre, hvor man kan sige, at størstedelen af eleverne har sikret sig, at de motiver der indfanges kan genkendes som noget "religiøst". De er således for så vidt engagerede $i$ at opretholde de genkendelige kategorier og positioneringer. Kollagerne viser en flerhed af religiøse udtryk og indtryk, men de holder sig hovedsageligt indenfor kristne eller islamiske symboler, handlinger og tegn. Hvor der på mindmap var en større variation af nævnte input, der f.eks. gik på jødedom, hinduisme osv. så er der er i kollagerne umiddelbart tale om en indsnævring af billedlige repræsentationer af religiøsitet. Det er således interessant at se, hvordan den hverdagslige kontekst er gennemsyret af religiøse markeringer, og at de markeringer der særligt får plads er de, der umiddelbart kan siges at repræsentere kristendom og islam. Det siger både noget om eksisterende diskursive regimes of representations, hvor vi lever i et samfund, hvor de to religioner er mest omdiskuterede og synlige, men det siger også noget om, hvem der tager billederne, og hvor det er muligt at repræsentere og synliggøre religiøsitet.

For det andet bliver flerheden af religiøsitet set og fotograferet $i$ forskellige lokationer og fra forskellige positioner, som følger det diskursive skel imellem det offentlige og det private/det muslimske og det ikke-muslimske i forhold til, hvordan skole og hjem kommer til syne. Kirkens omnipotente tilstedeværelse i kollagerne vidner om betydningen af lokalmiliøet, og synliggør, hvordan religiøsitet i form af kristenhed, indtager en central plads $i$ det lokale hverdagsliv - ikke som en praksis man nødvendigvis udøver, men som en materiel og arkitektonisk tilstedeværelse, som præger det lokale bybillede. Kirken er en fast del af det landskab, som elevernes hverdag udspiller sig i. Hjemmet rummer images og motiver af religiøs praksis, særligt muslimskhed, imens skolen kommer til syne $\mathrm{i}$ fotos af særligt juletraditionelle symboler. Skolens status som et sted, hvor man lærer om religion (og ikke praktiserer religion), og hvor kristendommen har en særskilt status, reproduceres i kollagerne.

Muslimskheden er til stede på skolen via de muslimske elever, som er engagerede $i$ daglige forhandlinger og grænsedragninger i forhold til de andre elever i klassen. Muslimskheden i skolen manifesterer sig f.eks. i foto af en pige med tørklæde (bijab), men derudover må muslimskhedens materielle udtryk og den islamiske praksis situeres andre steder. Det siger noget om det rum for forhandling og positionering, som skoleelever med muslimsk baggrund navigerer i, hvor skolen på en og samme gang kan inkludere, men samtidig ekskludere særlige former for muslimskheder (se også Khawaja 2014). Muslimskheden er til stede og der gives plads til den i skolen, men den skal helst ikke være for synlig i skolens rum, og således ikke antage en for forstyrrende karakter (ibid. se også Jensen \& 
Kühle 2013). Det bliver på denne måde via billederne muligt at få indblik $\mathrm{i}$ de eksisterende mere eller mindre synlige manifestationer af religiøs praksis, og hvordan muligheden for at synliggøre muslimsk praksis indenfor eller udenfor hjemmets fire vægge er forbundet med bredere magtrelationelle strukturer af minorisering og majorisering og af sekulære og religiøse imaginaries. Der eksisterer generelt en forventning om privatisering af religiøs praksis, som, synes forstærket $\mathrm{i}$ forhold til muslimsk praksis.

I forhold til det indledende spørgsmål om, hvorvidt der er plads til religiøsitet i skolen, og hvis der er plads, i hvilke former og på hvilke måder, kan man sige, at religiøsitet ses manifesteret inden for skolen, men det er særligt religiøse symboler og images, som er associeret med kristenhed og de traditioner, der er forbundet med jul. Nancy Woodman (2013) fremhæver, at religion er forbundet med sociale magtstrukturer, og som konsekvens heraf priviligeres og hyper-synliggøres nogle særlige versioner af religiøs praksis og religion fremfor andre. I elevernes fotos ses, at kristenheden er hyper-synlig i det offentlige rum, både i skolen og lokalmiljøet, imens de islamiske symboler og praksisser hyper-synliggøres i den private sfære. Man kan i denne sammenhæng pege på en hyperprivatisering af muslimskheden. Det er udtryk for et grundlæggende magtforhold imellem minoritet og majoritetsreligion, som også spiller ind på skolens status som majoritetskontekst.

For det tredje viser kollagerne hen imod en flerhed af mulige positioneringer, hvor de i klassen dominerende skel imellem troende/ikke troende, og muslim/ikke-muslim, bliver aktualiseret via de situationer, artefakter og symboler, som gøres til objekt for kameraet. De personlige tolkninger af religiøsitet bliver synlige via elevernes forskellige blikke på religion. Det er dog ikke alle billeder, der kan siges at afsløre, hvem og dermed fra hvilken subjekt position det pågældende foto er taget. Billederne fra skolens rum og fra lokalmiljøet, herunder særligt kirken, muliggør en positionering, hvor ens personlige praksis og erfaring med religiøsitet ikke i lige så høj grad bliver synlig, som i de fotos der er taget fra hjemmets fire vægge. Billeder fra privatsfæren peger ofte på egen og/eller familiepraksis, imens at fotos fra skolen i første omgang udtrykker positionen som skolelev. Positioneringerne via billederne siger også noget om den visuelle/fotografiske tilblivelsesproces, hvor positioneringens refleksive og interaktive dimensioner kollapser. Eleverne bliver til som subjekter i og med at de gør bestemte ting, situationer, steder til objekt for deres fotografiske linser, og på denne måde fletter selvkonstruktionen sig ind i konstruktionen af religion, hverdagsliv, skole, familie osv.

For det fjerde siger kollagerne noget om selve den metodiske tilgang, hvor brugen af fotos på den ene side levendegør religiøs praksis, men på den anden side også fastfryser og iscenesætter den. I forhold til den fotografiske fremstilling af muslimskhed ses, at det via kameraets linse er muligt at få indblik i den privatiserede og ikke altid offentligt synlige religiøse praksis, men på den anden side er det via fotos oftest kun muligt at få indfanget de materielle udtryk for religiøs praksis. Det teoretiske perspektiv på den hverdagslige religiøsitet gør det hertil muligt at indfange religiøse udtryk som del af børnenes hverdagspraksis i skolen, hjemmet og lokalområdet, og man kan i denne forbindelse tilføje, 
at barneperspektivet er et metodisk forsøg på magtrelationelt at gøre elevernes blikke på deres hverdagsliv til forgrund. Når eleverne får et kamera, som de kan anvende indenfor og udenfor skolen, bliver de i det moment positioneret som ansvarlige, aktive subjekter (se også Winther 2004: 25-26, Rasmussen 2013: 207), og det er muligt, at undersøge konstruktionen af f.eks. minoritets- og majoritetsreligiøse udtryk fra deres perspektiver. Religiøsitet og religion undersøges "nedefra" ved at eleverne får mulighed for at transformere og udtrykke deres stemmer og perspektiver i form af fotos. Det var netop det, som var formålet med at uddele engangskameraer til eleverne i de to femte klasser. Det har dog på den anden side nogle etiske konsekvenser, som at det kan være vanskeligt at bibeholde anonymitet og beskytte data om hvilken skole og hvilke elever, der har været involveret i projektet. Jeg har således nøje udvalgt hvilke billeder, jeg deler i denne artikel, og det betyder også, at ikke alle elementer af elevernes fotoproduktion kan vises.

Kollagerne og klassediskussionen viser samlet set forskellige elevhverdage, som er bundet sammen af en deltagelse på tværs af kontekster, der på forskellig vis er gennemsyret af religiøse udtryk og motiver. Der er på denne måde tale om et sammensurium, hvor muslimskheden hensættes til den private hjemlige sfære, imens kristenheden og julen både ses repræsenteret hjemme og i de offentlige rum som skolen og lokalmiljøet. Det er naturligvis ikke et udtømmende billede af elevernes hverdagslige erfaringer med religiøsitet, men mindmap samt billedmaterialet giver et indblik i hvilke diskurser, der er på spil om religion og religiøsitet og hvordan disse diskursive regimes spiller sammen med elevernes mulighed for at synliggøre religiøsitet herunder muslimskhed - på tværs af deres hverdagsliv indenfor og udenfor skolen.

\section{Forfatterpræsentation}

Iram Khawaja er ph.d. i psykologi og ansat som post.doc ved Institut for Uddannelse og Pædagogik, (DPU), Aarhus Universitet. Hun har i en lang årrække beskæftiget sig med børn og unge med muslimsk og etnisk minoritetsbaggrund. Hendes forskningsmæssige fokus har særligt været rettet imod konstruktionen af fællesskab, identitet og belonging i forskellige pædagogiske sammenhænge i forhold til diskursive og sociale processer af inklusion og eksklusion.

\section{Referencer}

Abbas, Tahir, 2007: "Muslim minorities in Britain: Integration, multiculturalism and radicalism in the post-7/7- Period", i: Journal of Intercultural Studies, 28, 3: 287 - 300

Ammerman, Nancy, 2007: "Studying everyday religion - Challenges for the future", i: Nancy Ammerman (red.): Everyday Religion- Observing Modern Religious Lives, Oxford University Press, New York.

Andenæs, Agnes, 1991: "Fra undersøkelsesobjekt til medforsker? Livsformsintervju med 4-5-åringer", i: Nordisk Psykologi. Vol 43. No. 4: $274-292$ 
Anderson, Sally, 2011: "Civil sociality and childhood education", i: Bradley Levinson, Mira Pollock (red.): Blackwell Companions to Anthropology: A Companion to the Anthropology of Education. Vol. 12. Wiley-Blackwell, New York.

Asad, Talal, 1993: Genealogies of Religion-Discipline and reasons of power in Christianity and Islam. The John Hopkins University Press, London.

Barad, Karen, 1998: "Getting real: Technoscientific practices and the materialization of reality", i: Differences: A Journal of Feminist Cultural Studies, Vol. 10, No. 2: 87-128.

Billig, Michael, 1995: Banal Nationalism. Sage Publications, London.

Brah, Avtar, 2007: "Non-binarized identities of similarity and difference", i: Margaret Wetherell, Michelynn LaFlechen \& Robert Berkeley (red.): Identity, Ethnic Diversity and Community Cobesion, Sage Publications, London.

Butler, Judith, 1999: Gender Trouble - Feminism and the Subversion of Identity. Routledge, New York.

de Certeau, Michel, 1984: The Practice of Everyday Life. University of California Press, Berkeley.

Coles, Robert, 1990: The Spiritual Life of Children. Houghton Mifflin Company, Boston.

Davies, Bronwyn \& Rom Harré, 1990: "Positioning: The discursive production of selves", i: Journal of the Theory of Social Behaviour. Vol. 20: 43-63.

Davies, Bronwyn, 2000: A Body of Writing- 1990-1999. AltaMira Press, Walnut Creek.

Dessing, Nathal, 2013: "How to study everyday Islam", i; Nathal Dessing, Nadia Jeldtoft, Jørgen Nielsen \& Linda Woodhead (red.): Everyday Lived Islam in Europe. Ashgate, London.

Dessing, Nathal \& Nadia Jeldtoft, Jørgen Nielsen \& Linda Woodhead, 2013: "Introduction", i: Nathal Dessing, Nadia Jeldtoft, Jørgen Nielsen \& Linda Woodhead (red.): Everyday Lived Islam in Europe. Ashgate, London.

El Haj, Thea Renda Abu, 2010: “"'The Beauty of America”: Nationalism, education, and the war on terror", i: Harvard Educational Review Vol. 80 No. 2: 242-274.

Gilliam, Laura \& Eva Gulløv, 2012: Civiliserende institutioner. Om idealer og distinktioner i opdragelse, Århus Universitetsforlag. Århus.

Gilliam, Laura, 2014: "Being a good, relaxed or exaggerated Muslim: Religiosity and masculinity in the social world of Danish schools", i: Mark Sedgwick (red.): Making European Muslims. Religious Socialization among Young Muslims in Scandinavia and Western Europe. Routledge, London.

Gulløv, Eva \& Susanne Højlund, 2010: Feltarbejde blandt born. Metodologi og etik i etnografisk borneforskning. Gyldendal, København.

Hall, Stuart, 2001: "The spectacle of the other", i; Margaret Wetherell, Stephanie Taylor \& Simeon Yates (red.): Discourse Theory and Practice: $A$ reader. The Open University Press, Sage Publications, London.

- 2003: "Cultural identity and diaspora", i: Jana Evans Braziel \& Anita Mannur (red.): Theorizing Diaspora. Blackwell Publishers, Oxford.

Hellers, David, 1986: The Children's God. Chicago University Press, Chicago. 
Hirschkind, Charles, 2011: "Is there a secular body?", i: Cultural Anthropology, Vol. 26, Issue. 4: 633-647.

Jeldtoft, Nadia, 2013: "Spirituality and emotions: Making a room of one's own", i: Nathal Dessing, Nadia Jeldtoft, Jørgen Nielsen \& Linda Woodhead (red.): Everyday Lived Islam in Europe. Ashgate, London.

Jensen, Sidsel Vive \& Lene Kühle, 2013: "'School Islam' : Lived religion in the context of a secular public institution", i: Nathal Dessing, Nadia Jeldtoft, Jørgen Nielsen \& Linda Woodhead (red.): Everyday Lived Islam in Europe. Ashgate, London.

Jouili, Jeannette, 2009: "Negotiating secular boundaries: Pious micropractices of Muslim women in French and German public spheres", i: Social Anthropology, Vol. 17, nr. 4: 455-470.

Khawaja, Iram, 2001: "Minoritetsbarnet i den danske folkeskole - en kvalitativ undersøgelse af positionerings- og andetgørelsestendenser $\mathrm{i}$ den danske folkeskole", i: Psyke \& Logos. Vol. 22. No. 1: 244-272.

- 2010: "To Belong Everywhere and Nowhere": Fortallinger om Muslimskhed, Fallesgorelse og Belonging". Ph.d-afhandling, Roskilde Universitetsforlag, Roskilde.

- 2014: "Muslimness and prayer: The performance of religiosity in everyday life in and outside school", i: Marks Sedgwick (red.): Making European Muslims. Religious Socialization among Young Muslims in Scandinavia and Western Europe, Routledge, London.

Kofoed, Jette, 2004: Elevpli - inklusion-og eksklusionsprocesser blandt born i skolen. Ph.d-afhandling. Danmarks Pædagogiske Universitet, København.

Kofoed, Jette \& Dorthe Staunæs, 2014: "Visuel metode som affektivt wunderkammer", i: Lene Tanggaard, Frederik Thuesen \& Kathrine Vitus (red.): Konflikt $i$ kvalitative studier. Hans Reitzels Forlag, København.

Korsgaard, Ove, 2009: "Demokrati som pædagogisk værdi", i: Vera: tidsskrift for padagoger, nr. 49: 13-17.

- 2012: Kampen om folket- Et dannelsesperspektiv på dansk historie gennem 500 ar. København, Gyldendal.

Kousholt, Dorte, 2005: "Hvad jeg lærte om forskning i min sovepose..." i Kvinder, Kon \& Forskning. Vol. 3: 60-62.

- 2011: Bornefallesskaber og familieliv: borns hverdagsliv på tvars af daginstitution og hjem. Dansk Psykologisk Forlag, København.

Lather, Patti, 2007: Getting Lost - Feminist Efforts toward a Double(d) Science, State University of New York Press, Albany.

Lægaard, Sune, 2012: "Unequal recognition, misrecognition and injustice: The case of religious minorities in Denmark", i: Ethnicities, Vol. 12, 2: 197-214.

McGuire, Meredith, 2008: Lived Religion: Faith and Practice in Everyday Life. Oxford University Press, Oxford.

Mørck, Line Lerche, 2006: Gransefallesskaber - Laring og overskridelse af marginalisering. Roskilde Universitetsforlag, Roskilde.

Munson, Ziad, 2007: "When a funeral isn't just a funeral : The layered meaning of everyday action", i: Nancy Ammerman (red.): Everyday Religion- Observing Modern Religious Lives, Oxford University Press, New York. 
Nielsen, Helle Schjellerup, 2013: "Fotografier som børns perspektiver på deres hverdagsliv", i: Kim Rasmussen (red.): Visuelle tilgange og metoder $i$ tvarfaglige padagogiske studier-en antologi baseret på erfaringer og indblik fra forskning, udviklingsarbejde og undervisning, Roskilde Universitetsforlag, Roskilde.

Olwig, Karen Fog \& Karsten Paerregaard, 2011: "Strangers" in the nation", i: Karen Fog Olwig \& Karsten Paerregaard (red.): The Question of Integration: Immigration, Exclusion and the Danish Welfare State, Cambridge Scholars Publishing, New Castle.

Rasmussen, Kim, 2013: Visuelle tilgange og metoder i tvarfaglige padagogiske studier - En antologi baseret på erfaringer og indblik fra forskning, udviklingsarbejde og undervisning. Roskilde Universitetsforlag, Roskilde.

Sedgwick, Mark, 2014: 'Islam in Christianity: religious education in the Danish folkeskole', i: Mark Segdwick (red.): Making European Muslims. Religious Socialization among Young Muslims in Scandinavia and Western Europe, Routledge, London.

Sheringham, Michael, 2000: "Attending to the everyday: Blanchot, Lefebvre, Certeau, Perec”, i: French Studies, Vol. LIV, No. 1:187-199.

Staunæs, Dorthe, 1998: Transitliv. København, Politisk Revy.

- 2001: "Engangskamera: et dialogisk metoderedskab eller et teknologisk fix?”, i: Henriette Christrup \& Arne Thing Mortensen \& Christina Hee Pedersen (red.): At begribe og bevage kommunikationsprocesser : om metoder i forskningspraksis. Roskilde Universitetscenter, Roskilde: 42-64.

- 2004: Kon, etnicitet og skoleliv. Forlaget Samfundslitteratur, Frederiksberg.

Søndergaard, Dorte Marie, 1996: Tegnet på Kroppen - Kon, koder og konstruktioner blandt unge voksne $i$ akademia. Museum Tuscalanums Forlag, København.

Winther, Ida, 2004: Hjem og Hjemlighed: En kulturfanomenologisk feltvandring, Ph.d. afhandling. Danmarks Pædagogiske Forlag, København.

Woodhead, Linda, 2013: "Tactical and strategic religion", i: Nathal Dessing \& Nadia Jeldtoft, Jørgen Nielsen \& Linda Woodhead (red.): Everyday Lived Islam in Europe. Ashgate, London. 